\title{
To Study on the Clamour Demand of Potato Product's according to Market
}

\author{
Rashmee Yadav $^{1 *}$, Brij Vikash Singh ${ }^{2}$ and Neelma Kunwar ${ }^{3}$ \\ ${ }^{1}$ SMS (Home Science), ${ }^{2}$ SMS (Animal Science), Krishi Vigyan Kendra, \\ Parwaha, Auraiya, UP, India \\ ${ }^{3}$ Department of Home science (Extension Education), \\ Chandra Shekhar Azad University of Agriculture and Technology, Kanpur, UP, India \\ *Corresponding author
}

\begin{abstract}
A B S T R A C T
The study reveals that consumer preferences for potato products in the selected study area. 96.7 per cent of respondents preferred aloo bhujia which was easily available $(70.0 \%)$, was in convenient packaging $(26.7 \%)$, at affordable price $(60.0 \%)$ and good for taste $(15.0 \%)$ whereas, 96.0 per cent farm women gave their preference for aloo tikki in which 67.3 per cent said that it was easily available in all places, 53.3 per cent opined about affordable price and 66.7 per cent preferred it only for taste. 97.0 per cent respondents preferred aloo paratha out of which 73.3 per cent were of the opinion that aloo paratha is the most easily available full meal in houses for both children and adults and 56.0 per cent consumed it only for taste. 100.0 per cent farm women preferred aloo chips in which 20.0 per cent liked its easy availability, 26.7 per cent found convenient packaging, 10.0 per cent bought it at affordable prices and 86.7 per cent consumed it only for taste. 53.3 per cent farm women preferred potato papad of which 6.7 per cent consumed it due to easy availability, 31.7 per cent found convenient packing, 6.7 per cent said that papads are available at affordable prices and 40.0 per cent consumed it only for taste while, 30.3 per cent of respondents liked finger chips only for taste. 25.3 per cent of respondents preferred potato masala fries for taste whereas, 16.7 per cent respondents preferred potato flakes ( 1.7 per cent) due to easy availability, 9.3 per cent found convenient packaging and 10.0 per cent consumed only for taste.
\end{abstract}

\section{Introduction}

There is no notable difference in consumption of snack food in the evenings or in parties whereas young age consumers prefer it as after home snack. The taste of snack food varies across the region. North Indian and South Indian consumers prefer spicy flavored snacks while as Western and Eastern region consumers have shown preference to tomato and cheese based flavors. Potato chips produced by both small-scale processing industries have been widely available in the market. The demand for potato chips that are regarded as an attractive palatable snack has shown an increasing trend.

Market observation indicates that better product attributes and product promotion of large-scale produced potato chips may affect the market for those produced on a smallscale. 
However, to date there has been very little study of consumer behaviour with regard to both types of potato chips. This type of research could provide insights about consumer decisions to purchase a particular product that may be useful for product development or improvement.

\section{Materials and Methods}

The study was conducted in Kannauj district. Two blocks Kannauj and Chhibramau were selected in this study. Ten villages were selected out of both selected blocks Total 300 farm women were selected. Dependent and independent variables such as age, education, caste, land holding and milch animals were selected. The statistical tools such as mean, rank, Fisher ' $t$ ' test, Cr were used.

\section{Results and Discussion}

The data in table 5.3 shows the distribution of farm women according to caste. 45.7 per cent of farm women belonged to O.B.C. whereas, 32.6 per cent of respondents belonged to SC/ST category. 21.7 per cent of farm women belonged to general category in the study area. Generally, upper caste and large farm women hire farmers of lower caste as daily wage labourers on their fields to do the cultivation of vegetables.

Mostly Saini, Kachhi, dalits, etc. work as lower caste labourers in vegetable growing and $\mathrm{OBC}$ women were mostly seen involved in livestock management such as dairy, sheep and goat rearing, etc. Lower caste women were mostly involved in agricultural activities such as weeding, harvesting etc. Potato cultivation is a caste oriented activity and mainly cultivated at a small scale.

Data presented in table 2. reveals the consumer preferences for potato products in the selected study area. 96.7 per cent of respondents preferred aloo bhujia which was easily available $(70.0 \%)$, was in convenient packaging $(26.7 \%)$, at affordable price $(60.0$ $\%)$ and good for taste $(15.0 \%)$ whereas, 96.0 per cent farm women gave their preference for aloo tikki in which 67.3 per cent said that it was easily available in all places, 53.3 per cent opined about affordable price and 66.7 per cent preferred it only for taste. 97.0 per cent respondents preferred aloo paratha out of which 73.3 per cent were of the opinion that aloo paratha is the most easily available full meal in houses for both children and adults and 56.0 per cent consumed it only for taste.

100.0 per cent farm women preferred aloo chips in which 20.0 per cent liked its easy availability, 26.7 per cent found convenient packaging, 10.0 per cent bought it at affordable prices and 86.7 per cent consumed it only for taste. 53.3 per cent farm women preferred potato papad of which 6.7 per cent consumed it due to easy availability, 31.7 per cent found convenient packing, 6.7 per cent said that papads are available at affordable prices and 40.0 per cent consumed it only for taste while, 30.3 per cent of respondents liked finger chips only for taste.

25.3 per cent of respondents preferred potato masala fries for taste whereas, 16.7 per cent respondents preferred potato flakes (1.7 per cent) due to easy availability, 9.3 per cent found convenient packaging and 10.0 per cent consumed only for taste.

Potato is the fourth most important vegetable crop and is a wholesome food. In India, potatoes have been utilized largely for consumption as fresh potatoes and the major part of potato harvest (approx. $68.5 \%$ ) goes to domestic table consumption. Whereas, in the developed countries, table potato utilization is merely $31 \%$, rest being frozen French fries (30\%), chips and shoestrings (12 $\%)$ and dehydrated products $(12 \%)$. 
Table.1 Distribution of farm women according to caste

\begin{tabular}{|c|l|c|c|}
\hline SI.No. & Caste & Frequency & Per cent \\
\hline 1. & General & 65 & 21.7 \\
\hline 2. & O.B.C. & 137 & 45.7 \\
\hline 3. & SC/ST & 98 & 32.6 \\
\hline & Total & 300 & 100.0 \\
\hline
\end{tabular}

Table.2 Consumer preferences for potato products

\begin{tabular}{|c|c|c|c|c|c|c|c|c|}
\hline \multirow{3}{*}{$\begin{array}{l}\text { Sl. } \\
\text { No. } \\
1 .\end{array}$} & \multirow{3}{*}{$\begin{array}{l}\text { Products } \\
\text { Aloo } \\
\text { Bhujia }\end{array}$} & \multirow{3}{*}{$\begin{array}{c}\text { Yes } \\
\\
290 \\
(96.7)\end{array}$} & \multirow{3}{*}{$\begin{array}{c}\text { No } \\
10(3.3)\end{array}$} & \multicolumn{5}{|c|}{ If yes, then } \\
\hline & & & & $\begin{array}{c}\text { Easy } \\
\text { availability }\end{array}$ & $\begin{array}{c}\text { Convenient } \\
\text { packaging }\end{array}$ & \multirow{2}{*}{$\begin{array}{c}\begin{array}{c}\text { Affordable } \\
\text { prices }\end{array} \\
180(60.0)\end{array}$} & \multirow{2}{*}{$\begin{array}{c}\begin{array}{c}\text { Nutritious } \\
\text { value }\end{array} \\
-\end{array}$} & \multirow{2}{*}{$\begin{array}{c}\begin{array}{c}\text { Only } \\
\text { taste }\end{array} \\
45(15.0)\end{array}$} \\
\hline & & & & $210 \quad(70.0)$ & $80 \quad(26.7)$ & & & \\
\hline 2. & $\begin{array}{l}\text { Potato } \\
\text { flakes }\end{array}$ & $\begin{array}{c}50 \\
(16.7)\end{array}$ & $250(83.3)$ & $5 \quad(1.7)$ & $28 \quad(9.3)$ & - & - & $30(10.0)$ \\
\hline 3. & $\begin{array}{l}\text { Potato } \\
\text { powder }\end{array}$ & - & $\begin{array}{c}300 \\
(100.0)\end{array}$ & - & - & - & - & - \\
\hline 4. & $\begin{array}{l}\text { French fries } \\
\text { (Finger } \\
\text { chips) }\end{array}$ & $\begin{array}{c}91 \\
(30.3)\end{array}$ & $209(69.7)$ & - & - & - & - & $91(30.3)$ \\
\hline 5. & $\begin{array}{l}\text { Masala } \\
\text { fries }\end{array}$ & $\begin{array}{c}76 \\
(25.3)\end{array}$ & $224(74.7)$ & - & - & - & - & $76(25.3)$ \\
\hline 6. & $\begin{array}{l}\text { Potato } \\
\text { chips }\end{array}$ & $\begin{array}{c}300 \\
(100.0)\end{array}$ & - & $\begin{array}{c}60 \\
(20.0)\end{array}$ & $80(26.7)$ & $30(10.0)$ & $6(2.0)$ & $\begin{array}{c}260 \\
(86.7)\end{array}$ \\
\hline 7. & $\begin{array}{l}\text { Potato } \\
\text { papad }\end{array}$ & $\begin{array}{c}160 \\
(53.3)\end{array}$ & $140(46.7)$ & $20 \quad(6.7)$ & $95(31.7)$ & $20(6.7)$ & $10(3.3)$ & $\begin{array}{c}120 \\
(40.0)\end{array}$ \\
\hline 8. & $\begin{array}{l}\text { Potato } \\
\text { wedges }\end{array}$ & - & $\begin{array}{c}300 \\
(100.0)\end{array}$ & - & - & - & - & - \\
\hline 9. & $\begin{array}{l}\text { Potato } \\
\text { waffle }\end{array}$ & - & $\begin{array}{c}300 \\
(100.0)\end{array}$ & - & - & - & - & - \\
\hline 10. & Aloo Vadi & $\begin{array}{c}119 \\
(39.7)\end{array}$ & $181(60.3)$ & $\begin{array}{c}90 \\
(30.0)\end{array}$ & $8(2.7)$ & - & - & $62(20.7)$ \\
\hline 11. & Potato bites & - & $\begin{array}{c}300 \\
(100.0)\end{array}$ & - & - & - & - & - \\
\hline 12. & $\begin{array}{l}\text { Mumbai } \\
\text { vada }\end{array}$ & - & $\begin{array}{c}300 \\
(100.0)\end{array}$ & - & - & - & - & - \\
\hline 13. & Aloo Tikki & $\begin{array}{c}288 \\
(96.0)\end{array}$ & $12(4.0)$ & $202 \quad(67.3)$ & - & $160(53.3)$ & - & $\begin{array}{c}200 \\
(66.7)\end{array}$ \\
\hline 14. & $\begin{array}{l}\text { Frozen } \\
\text { potato } \\
\text { snacks }\end{array}$ & - & $\begin{array}{c}300 \\
(100.0)\end{array}$ & - & - & - & - & - \\
\hline 15. & $\begin{array}{l}\text { Aloo } \\
\text { paratha }\end{array}$ & $\begin{array}{c}291 \\
(97.0)\end{array}$ & 09 (3.0) & $\begin{array}{c}220 \\
(73.3)\end{array}$ & - & - & - & $\begin{array}{c}168 \\
(56.0)\end{array}$ \\
\hline
\end{tabular}

(Figures in parentheses denote the percentage of respective values) 
The processing of potatoes in the country was not in vogue till 90's and with the openings of organized processing by multinationals and indigenous players, potato processing industry has grown manifolds. During 2007-2008 about 7 per cent of potato production was used by processing industry and the sector is still increasing at a rapid rate. The pattern of Indian potato industry suggests that the demand for potatoes for processing purpose is expected to rise rapidly over next 40 years for french fries (11.6\% ACGR) followed by potato flakes/ powder $(7.6 \%)$ and potato chips $(4.5 \%)$. The demand for processing quality potato is expected to rise to 25 million tonn during the year 2050.

Potatoes can be processed into various forms such as chips, fries, dehydrated products (dehydrated chips, dice or cubes, waris, papads, flakes, granules and flour) potato starch, etc. Potato processing is carried out by organized and unorganized sectors. Organized sector mainly involves large manufactures with brand names.

Whereas, small manufactures that are preparing processed potato products for local market without any brand name come under unorganized sector. Organized sector mainly prepares French fries, Aloo Bhujia, potato flakes and flour. Potato chips are prepared by both organized and unorganized sectors.
Along with potato chips, dehydrated potato products such as potato shreds and potato chips are also made by unorganized sector. For processing of potatoes, they have to have certain minimum attributes of quality.

\section{References}

Butt, M. and Sahi, S.T. (2008). Role of mass media for enhancing potato production. Indian Research Journal of Extension Education 8 (1).

Kuma, B. and Limenih, B. (2015). "Women Farmers in Practices: Opportunities and Challenges in Accessing Potato Production Technologies in Welmera Ethiopia". Asian Journal of Agricultural Extension, Economics and Sociology; 6(3): 149-157.

Lacy, K. and Huffman, W.E. (2016). "Consumer demand for potato products and willingness-topay for low-acrylamide, sulfite-free fresh potatoes and dices: evidence from lab auctions". Journal of Agricultural and Resource Economics; 41(1):116137.

Punyatoya, P.; Sadh, A., and Mishra, S.K. (2014). Role of brand globalness in consumer evaluation of new product branding strategy". Journal of Brand Management; 21(2) : 171-178.

\section{How to cite this article:}

Rashmee Yadav, Brij Vikash Singh and Neelma Kunwar. 2020. To Study on the Clamour Demand of Potato Product's according to Market. Int.J.Curr.Microbiol.App.Sci. 9(06): 12801283. doi: https://doi.org/10.20546/ijcmas.2020.906.158 